\title{
Presence and Detection of Pharmaceutical Substances (Diclofenac, 17- $\beta$-estradiol, 17- $\alpha$-etilinestradiol) in the Environment. Future Challenges for Lithuania
}

\author{
Inga Baranauskaitė, Jolanta Dvarionienė \\ Institute of Environmental Engineering, Kaunas University of Technology, Lithuania \\ cross $^{\text {ref }}$ http://dx.doi.org/10.5755/j01.erem.68.2.7378
}

(Received in June, 2014; accepted in June, 2014)

\begin{abstract}
Prevalence and migration of pharmaceutical substances in the aquatic cycles are among the most negotiable and environmentally relevant problems all over the world. On August 12, 2013 Directive 2013/39/EU of the European Parliament and Council was adopted; that Directive being the first document to contain pharmaceutical substances (diclofenac (DCF), 17- $\beta$-estradiol (E2) and 17- $\alpha$-ethinylestradiol (EE2)) included in the Monitoring list. According to the right-down research it is believed that the mentioned substances can cause a harmful effect on the biota and the natural environment.

To predict and to control the penetration of pharmaceutical substances into the environment, as well as to reduce their escape into it, the sources of their formation, their consumers, and the ways of their penetration into the environment are to be analyzed, their ability to change and to accumulate in the environment should be realized.

To achieve this objective the legal basis applicable to the pharmaceutical substances (DCF, E2 and EE2) is analyzed in this paper, the volumes of Lithuanian sales of pharmaceutical substances (DCF, E2 and EE2) are determined, and the tendencies of sales alterations are discussed. The research done in this field is reviewed through the analyses and evaluation of the toxicological significance of these substances in the environment, through flows and sources of their penetration into the natural environment, the materials decomposition in the aquatic environment, and through the global experience in removal of pharmaceutical substances from wastewater and wastewater disposal in Lithuania.
\end{abstract}

Keywords: diclofenac, 17- $\beta$-estradiol, 17- $\alpha$-ethinylestradiol, wastewater treatment

\section{Introduction}

Pharmaceutical substances and their metabolites, generally known as active pharmaceutical compounds, have been found in surface water, groundwater and drinking water since 1990. For a while their prevalence and persistence in the environment and the aquatic cycles have been recognized as a negotiable issue both among scientists and at the political level all around the globe.

On August 12, 2013 Directive 2013/39/EU of the European Parliament and Council was adopted and that document partially replaced the provisions of Directives 2000/60/EC and 2008/105/EC regarding priority substances in the area of aquatic policy.
The pharmaceutical substances diclofenac (DCF), 17- $\beta$-estradiol (E2) and 17- $\alpha$-ethinylestradiol (EE2)) (hereinafter referred to as DCF, E2 and EE2) were for the first time included in the Monitoring list. It does not mean any doubts about therapeutic value of these substances, however on the basis of the newest scientific knowledge the potential harmful effect of these substances existence in the water was considered.

The pharmaceutical substances used by human beings usually penetrate into the environment through wastewater treatment plants, they also often penetrate due to unsuitable disposal, i.e., when the substances are poured out directly to sewerage or disposed of 
together with household waste. In Germany, Austria and Great Britain $17.7 \%$ of pharmaceutical substances remain unused, the majority of them being transported to landfills (Längin et al., 2009). Deliberate anthropogenic human activity induces a negative long-lasting effect on the environment.

Chemical pollution of the surface water even in very low concentrations (ng/l and $\mu \mathrm{g} / \mathrm{l}$ ) can pose a threat to the aquatic environment resulting in the acute and long-lasting effect on aquatic organisms, accumulation of pollutants in the ecosystem and possible decay of habitats and biodiversity. To prevent the adverse effect and irreversible damage, the precautionary principle is to be followed, namely the existing situation evaluated, the potential scenarios predicted and all taken steps contemplated. Thus, to manage the penetration of pharmaceutical substances entrance into the natural environment and to reduce the arrising risk, main activities inducing the drug accesibility by a final consumer must be determined, the mechanism of the substance penetration into the environment and their interaction with each other have to be perceived.

The presence of DCF, E2 and EE2 in the environment has not been studied in Lithuania so far, their measurements in the aquatic environment have not been made. Therefore, to assess the risk to the environment caused by these substances, their primary analysis is to be made. The review of the applicability of legal basis for DCF, E2 and EE2 in the environment, assessment of their toxicological significance in the natural environment, the analysis of the ways and sources of their penetration into the environment, their decomposition and fate in the aquatic environment, the analysis and management of the removal of DCF, E2 and EE2 from wastewater, technologies used and the analysis of the substances consumption in Lithuania are recognized as the main tasks of this work.

\section{Methods}

Collection, analysis, and systematization of the analytical part data were performed using various foreign and Lithuanian data bases (referred to the Lithuanian sources). The collection of the data on production, use and disposal of drugs in Lithuania was performed during the interviews with pharmacists, officials of the State Medicines Control Agency, the collection of the data on the use of veterinary drugs was performed during the interviews with the inspector of the State Food and Veterinary Service, the collection of the data on the accounting information of the management of medical and pharmaceutical waste was performed in the interviews with specialists of the Environmental Protection Agency.

Consumption of the analyzed pharmaceutical substances in Lithuania and the Baltic States is presented with the number DDD that represents 1000 of the residents per day. The data of the drugs sold or prescribed that is presented by number DDD/1000 of the residents per day shows the approximate assessment of part of the residents treated with certain drugs in the defined area. For example, the expression $10 \mathrm{DDD} / 1000$ of the residents per day shows that approximately 1 percent of residents are treated with the certain drugs daily.

\section{The legal regulatory environment for the materials analyzed and their importance in the field of aquatic policy}

Water Framework Directive 2000/60/EC (hereinafter referred to as WFD) determines the actions of the Community in the field of aquatic policy, also the strategy of the battle against aquatic pollution. Article 16 of WFD presents the requirement in regard of the Commision for both determining the priority substances among the ones which via the aquatic environment may pose a significant risk, and determining the EU environmental quality standards (EQS) for these substances in the water, residues and/or biota. In 2001 the first list of 33 priority substances was made and in 2008 the EQS of these substances were determined (Directive 2008/105/EC). Directive 2008/105/EC carries a requirement for revising and updating of EQS. In accordance with Article 16 of WFD the Commission is also requested to review and update periodically the list of priority substances.

Directive 2013/39/EU of the European Parliament and Council. After recent revision of the priority substances list, in accordance with Directives 2000/60/EC and 2008/105/EC the European Council has made the conclusion that it is appropriate to change this list partially and to determine new substances which must be taken into account when taking priority actions in their regard at the Union level; the environmental quality standards (EQS) should be updated, too. That conclusion was accepted and legitimized on August 12, 2013 by Directive 2013/39/EU of the European Parliament and Council that has partially replaced the provisions of Directives 2000/60/EC and 2008/105/EC on the priority substances in the field of aquatic policy. The list of 33 priority substances presented in the Directive has been supplemented with additional 15 substances. The Monitoring list, which was included for collecting more effectively the monitoring data on chemical substances that are considered to be candidats in the priority list, is mentioned for the first time. Due to their toxicological significance determinated by relatively high costs and distribution of materials in the natural environment, 3 pharmaceutical active substances diclofenac, $17-\beta$-estradiol (E2) and $17 \alpha$ ethinylestradiol (EE2) have been included in the list for the first time. In the future the decision will be made whether it is worth to include these substances into the list of the substances that are monitored by the EU in accordance with the priority procedure.

Political preparatory actions before the introduction of Directive 2013/39/EU on the national legal basis. The plan of the actions in management of 
the substances included in the Monitoring list, the situation and the recommendations for further actions monitoring results, the conclusions about the existing are presented in Directive 2013/39/EU (see Table 1).

Table 1. Strategy (in accordance with Directive 2013/39/EU) of monitoring the substances that are part of the Monitoring list in Member states

\begin{tabular}{|c|c|c|c|}
\hline Period & Actions & $\begin{array}{l}\text { Position in the Directive } \\
\text { 2013/39/ES }\end{array}$ & $\begin{array}{l}\text { The responsible } \\
\text { country }\end{array}$ \\
\hline Before September 14, 2014 & The compiled Monitoring list & $\begin{array}{l}\text { Modifications } 2008 / 105 / E C ; \\
\text { part } 2 \text { of article } 8 b\end{array}$ & Commission \\
\hline Every 24 months & Updating of the Monitoring list & $\begin{array}{l}\text { Modifications } 2008 / 105 / E C ; \\
\text { part } 2 \text { of article } 8 b\end{array}$ & Commission \\
\hline $\begin{array}{l}\text { Before September 14, } 2015 \text { or } \\
\text { within } 6 \text { months after the date } \\
\text { of new substance inclusion in } \\
\text { the list }\end{array}$ & $\begin{array}{l}\text { The monitoring period begins } \\
\text { that must last at least for } 12 \\
\text { months and at least once a year }\end{array}$ & $\begin{array}{l}\text { Modifications 2008/105/EC; } \\
\text { part } 3 \text { of article } 8 b\end{array}$ & Member states \\
\hline $\begin{array}{l}\text { Within } 15 \text { months from } \\
\text { September } 14,2015 \text { or within } \\
21 \text { months from the day of the } \\
\text { monitoring list formation }\end{array}$ & $\begin{array}{l}\text { Presentation of the monitoring } \\
\text { report }\end{array}$ & $\begin{array}{l}\text { Modifications } 2008 / 105 / \mathrm{EC} \text {; } \\
\text { part } 4 \text { of article } 8 \mathrm{~b}\end{array}$ & Member states \\
\hline $\begin{array}{l}\text { Every } 12 \text { months while the } \\
\text { substance is in the list }\end{array}$ & $\begin{array}{l}\text { Presentation of the monitoring } \\
\text { report }\end{array}$ & $\begin{array}{l}\text { Modifications } 2008 / 105 / \mathrm{EC} \\
\text { part } 4 \text { of article } 8 \mathrm{~b}\end{array}$ & Member states \\
\hline $\begin{array}{l}\text { Within } 2 \text { years from September } \\
13,2013\end{array}$ & $\begin{array}{l}\text { Development of the strategic } \\
\text { approach towards aquatic } \\
\text { pollution with pharmaceutical } \\
\text { substances }\end{array}$ & $\begin{array}{l}\text { Modifications 2008/105/EC; } \\
\text { article 8c }\end{array}$ & Commission \\
\hline $\begin{array}{l}\text { Before September 14, } 2017 \text { if } \\
\text { needed }\end{array}$ & $\begin{array}{l}\text { Suggestion of the measures for } \\
\text { elimination of the potential } \\
\text { effect of pharmaceutical } \\
\text { measures on the environment }\end{array}$ & $\begin{array}{l}\text { Modifications 2008/105/EC; } \\
\text { article 8c }\end{array}$ & Commission \\
\hline
\end{tabular}

Before the end of 2015 the period of monitoring of pharmaceutical substances in the aquatic environment should begin. Representative stations for their monitoring should be selected. In accordance with the methodology presented in article $8 \mathrm{~b}$ of the Directive the further calculation of the number of monitoring stations required in Lithuania is done.

A Member state must select at least one monitoring station, moreover, additional one station (A) must be selected, if more than one million of residents live in the selected area, also the number (B) that is equal to the area of that station $\left(\mathrm{km}^{2}\right)$ divided by 60 thousand (approximated to the nearest whole number) and plus the number of the stations (C) that is equal to the number of its residents divided by 5 million (approximated to the nearest whole number).

Therefore the number of monitoring stations in Lithuania (N) should be calculated as follows:

$\mathrm{N}=1+\mathrm{A}+\mathrm{B}+\mathrm{C}$

where:

$$
\begin{aligned}
& \mathrm{A}=1 ; \\
& \mathrm{B}=\frac{65000 \mathrm{~km}^{2}}{60000}=1.088 \\
& \mathrm{C}=\frac{2944459 \mathrm{gyv} .}{5000000}=0.58 .
\end{aligned}
$$

Here the number of residents at the beginning of 2014 is indicated (Statistics Lithuania, 2014).
In accordance with these calculations it is known that in Lithuania 4 monitoring stations that are suitable for the monitoring of DCF, E2 and EE2 should be selected during the nearest years. In the Directive the fact that the Member state can present sufficient, comparable and presentable data on the presence of these substances in the aquatic environment is mentioned too, thus the Member State can make decision not to carry out the monitoring of these substances in accordance with the mechanism of the monitoring list.

The environmental quality standards (EQS) of $D C F, E 2$ and EE2 that were determined by the Scientific Committee of Health and Environmental Risk. Directive 2008/105/EC of the European Parliament and Council states that good chemical condition of the water body can be achieved when complying with all the environmental quality standards EQS (AA (the annual average) - EQS reflects the chronic effect, i.e. provides protection from long-term irreversible effects, and MAC(the maximum allowable concentration)-EQS - reflects short-term negative consequences in the environment due to strong direct effect). The same Directive states that Member states of the EU can on their own set the EQS for residues and biota.

In accordance with the analysis of the reports of the EU Scientific Committee of the Impact on Health and the Environment the EQS determined for the tested substances are presented in Figure 1 (SCHER, EE2, 2011; JRC Scientific and policy reports, 2012). 

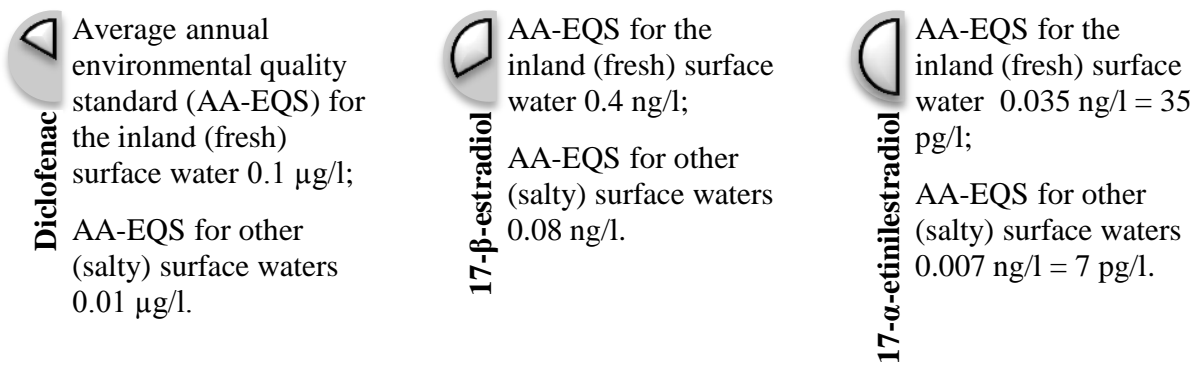

Fig. 1. DCF, E2 and EE2 environmental quality standards for water (SCHER, EE2, 2011; JRC Scientific and policy reports, 2012)

In accordance with Directive 2013/39/EU the existing EQS should be updated in the nearest future and the application of more strict environmental quality standards that were determined to the substances included in the list of priority substances should be started from 2015 in order to ensure good chemical condition of the surface water.

Helsinki Convention. The Helsinki Commission or the Baltic Marine Environment Protection Commission (HELCOM) is the institution that coordinates the implementation of the Helsinki Convention on protection of the Baltic Sea Basin Marine Environment adopted in 1974. In 1992 Lithuania became a member of this convention. The importance of its implementation is also emphasized in the EU strategy of the Baltic Sea Region that was among the priorities of the Lithuania's Presidency of the EU Council. The same as the Helsinki Convention it emphasizes the improvement of the condition of the Baltic Sea environment.

During one of the projects of HELCOM (CORESET) the mechanism of the effects has been proposed, this mechanism is concretized in accordance with particular indicators that are applied to the performance of the assessment of environmental condition (Helcom Core Set Indicators, 2010-2013). Among these indicators diclofenac and 17-alfa-ethinylestradiolum are included in the indicative group of pollutants. The proposed indicator value of water is $7.5 \mu \mathrm{g} / 1$ and $3.5 \mu \mathrm{g} / 1$, respectively
(Marine Research Consortium (MRC), 2012). The Marine Research Consortium has provided Lithuania with the $5^{\text {th }}$ report that contains the assessment of the Lithuanian Baltic Marine Environment condition and the human impact in accordance with the requirements of the European Union Directive of the Marine Strategy Framework, and the analysis of the criteria and indicators proposed by the European Commission. However, due to the lack of data and research the above mentioned DCF and EE2 indicators have not been presented in the report so far (MRC, 2013).

Legal basis regulating the presence of analyzed veterinary active substances in the environment. The legal act that restricts the residues of the analyzed substances is recognized as the main regulatory environment that is applied to these substances. The biggest allowable amount of the residues of veterinary drugs in foodstuffs of animal origin is determined by the Regulation (EU) No. 37/2010 of the Commission. According to this regulation both diclofenac and 17- $\beta$ estradiol are added to the list of the permitted substances, however only DCF is rationed (see Table 2). The maximum allowable concentration (MAC) of E2 is not applied, but, if necessary it is tested for zootechnical necessities in foodstuffs of animal origin. The testing of veterinary drug residues in the food is done annually, discrepancies in the regulation occur regularly.

Table 2. Pharmacologically active substance (DCF), its classification and maximum allowable concentration $(M A C)(O L L$ $15,2010)$

\begin{tabular}{|c|c|c|c|c|}
\hline $\begin{array}{l}\text { Pharmacologically } \\
\text { active substance }\end{array}$ & $\begin{array}{l}\text { Animal } \\
\text { species }\end{array}$ & MAC & $\begin{array}{l}\text { Target } \\
\text { tissues }\end{array}$ & $\begin{array}{l}\text { Therapeutic } \\
\text { classification }\end{array}$ \\
\hline \multirow[t]{9}{*}{ Diclofenac } & \multirow[t]{5}{*}{ Cattle } & $5 \mu \mathrm{g} / \mathrm{kg}$ & Muscles & \multirow{9}{*}{$\begin{array}{l}\text { Anti- } \\
\text { inflammatory } \\
\text { active substances, } \\
\text { non-steroidal anti- } \\
\text { inflammatory } \\
\text { active substances }\end{array}$} \\
\hline & & $1 \mu \mathrm{g} / \mathrm{kg}$ & Fats & \\
\hline & & $6 \mu \mathrm{g} / \mathrm{kg}$ & Liver & \\
\hline & & $10 \mu \mathrm{g} / \mathrm{kg}$ & Kidney & \\
\hline & & $0.1 \mu \mathrm{g} / \mathrm{kg}$ & Milk & \\
\hline & \multirow[t]{4}{*}{ Pigs } & $5 \mu \mathrm{g} / \mathrm{kg}$ & Muscles & \\
\hline & & $1 \mu \mathrm{g} / \mathrm{kg}$ & Skin and fats & \\
\hline & & $5 \mu \mathrm{g} / \mathrm{kg}$ & Liver & \\
\hline & & $10 \mu \mathrm{g} / \mathrm{kg}$ & Kidney & \\
\hline
\end{tabular}

The amount of diclofenac in the cattle muscles tested in the Panevezys county in 2008 exceeded its allowable concentration by approximately 6 times (see Table 2) (Milius J., 2010). During the period of 2004- 2010 it was found that the residues of diclofenac in the sample of pig muscles exceeded MAC 8 times and 6 times in the sample of cattle muscles (Gedvilaite D., 2013). The tests of pig muscles of 2013 revealed the fact that DCF concentrations also exceeded the maximum allowable concentration (21 samples among 2116 samples did not meet the allowable concentrations, 5 cases among those 21 were the cases of diclofenac concentration) 
(State Food and Veterinary Service of the Republic of Lithuania, 2013).

Lithuanian legislation provides that the drugs for a sick animal can be prescribed only by a veterinarian and the products that were made of the meat of the animal treated with medications (prescribed by veterinarian) cannot be consumed before the disappearance of the residues of veterinarian drugs from the organism of that animal. If they are detected, carcass meat should be utilized.

\section{Impact of tested substances on the natural environment}

Researchers have determined the marginal doses of DCF, E2 and EE2; after the trespass of these doses the toxic effect of these substances occurs (see Table 3 ). It has been already proved that the aquatic environment containing the treated wastewater discharged from the treated plants corresponds to the medium where the reproductive potential of fish is strongly affected, and this is due to the natural and synthetic hormonal substances that are found in the water, such as ethinylestradiol (EE2), which potentially interact with other substances influencing the endocrine system like polychlorinated biphenyls (PCB), pharmaceutical substances and surface-active agents (surfactants) (Plant J. A. et al., 2012).

Table 3. Toxic and ecotoxicological significance of the substances DCF, E2 and EE2

\begin{tabular}{|l|l|l||}
\hline $\begin{array}{l}\text { Substance and its concentration } \\
\text { at which the effects were } \\
\text { detected }\end{array}$ & The type of risk & Literature source \\
\hline Diclofenac; $0.5-50 \mu \mathrm{g} / \mathrm{l}$ & $\begin{array}{l}\text { Impact on the gill and kidney tissues of freshwater fish and } \\
\text { trout (Salmo trutta f. fario), this demonstrantes the } \\
\text { potential risk to fish popullations. }\end{array}$ & $\begin{array}{l}\text { Hoeger B. et al. 2005 } \\
\text { (Germany) }\end{array}$ \\
\hline $\begin{array}{l}\text { Diclofenac, E2 ir EE2; } \\
\sim 0.1 \mu \mathrm{g} / 1\end{array}$ & $\begin{array}{l}\text { Risk to the aquatic environment, chronic toxic effect (e.g. } \\
\text { suppressed polyp regeneration and impaired reproduction) }\end{array}$ & $\begin{array}{l}\text { Carlsson C., 2006 } \\
\text { (Sweden) }\end{array}$ \\
\hline $\begin{array}{l}17 \alpha \text {-ethinylestradiol } \\
\text { (EE2); 5-50 ng/l }\end{array}$ & $\begin{array}{l}\text { Steroidogenic acute protein regulatory and cytochrome P- } \\
\text { 450 mediation of salmon fry brain and kidney that is } \\
\text { evident in the cholesterol side-chain split expressions } \\
\text { which are modulated by time and concentration }\end{array}$ & $\begin{array}{l}\text { Lyssimachou A. and } \\
\text { Arukwe A., 2007 }\end{array}$ \\
\hline
\end{tabular}

Even very small amounts (ng/l) of synthetic hormones have an influence and can exert a negative effect on human and wild beasts' endocrine systems. 17 - $\alpha$-ethinylestradiol (EE2) used by humans as oral contraceptive is a basic synthetic hormone found in the samples of the environment. EE2 (also E2) is removed from the organism with urine and goes directly to wastewater as inactive glucuronide. Due to E. coli bacteria in wastewater it splits and turns into active strain of the substance (Doerr-MacEwen N. A., 2007). Approximately 54\% of the active EE2 accesses the wastewater together with urine, whereas $6 \%$ of it leaves with faeces (Speck U., 1976), E2 - 38\% and $62 \%$, respectively (Dusterberg B. et al, 1982). Such domestic wastewater is a complex mixture of chemical substances. It is known that these hormones affect the reproductive health of wild fish and undermine their successful reproduction, they can also affect other organisms. Kidd K. A. et al. (2007) have found out that the organism of male fish in Canada which live and are found not far from wastewater treatment plants produces vitellogenin (VTG) (protein that is normally synthesized by females during maturation of ovocytes), the tectiles of these fish produce the eggs of baby fish. It is found that this feminization has occured due to oestrogenic substances, such as natural oestrogens $17-\beta$-estradiol (E2) and the synthetic oestrogen - 17- $\alpha-$ ethinylestradiol (EE2), or weaker oestrogen imitators, such as nonylphenol. 5-6 ng/l of EE2 is the concentration of the substance that can cause feminization of fish (Kidd K. A. et al., 2007). It is important to mention that EE2 causes 10 times stronger toxic effect on biota compared to E2 (SCHER, EE2, 2011; JRC Scientific and policy reports, 2012). Unlike EE2 and E2, estrone (E1) and estriol (E3) are natural sex hormones and are not as strong as EE2. Generally, their potential could be described as follows: EE2> E2> E1> E3 (HELCOM report, 2013).

An active chemical substance of the drug diclofenac has gained more attention quite recently, when Pakistani population of white-backed vultures started to decline in 1990, in 2004 it reached the peak (Oaks J. L. et al., 2004). It was determined that diclofenac was the cause of disappearance of more than $95 \%$ of white-backed vultures population. This medicament causing the kidney failure was found in the bodies of wild birds (Doerr-MacEwen N. A., 2007).

\section{Sources, flows, prevalence and detection of pharmaceutical substances in the environment}

Sources of pharmaceutical substances and their flows in the environment. Toxicological significance and effects on human health are not the only problem associated with these substances. Great concern is shown to their accumulation and existence in the environment, to their participation in natural 
processes and to their impact on wild nature, biota and various ecosystems, also to the entrance of these substances to the human organism for a second time after their cycle in the natural environment (Heberer T., 2001; Plant J. A. et al., 2012). In order to control the outspread of pharmaceutical substances and their escape to the environment, the reasons of their behavior and their main sources must be primarily analyzed.

The patients consuming drugs, production companies and service sectors connected with wastewater collection systems are recognized to be the main factors causing the formation of the sources of the pharmaceutical substances consumed by humans. Hospitals, various drugs production devices, laboratorines, care or shelter homes, prisons or households are the examples of such sources (Plant J.
Veterinary drugs escape to the environment through farm animals or water farms, when they travel in the food chain. Active substances of veterinary drugs can escape to the environment during the treatment of pets or farm animals, when these animals evacuate, also when people process the meat of farm animals - in all these cases animal faeces enter the environment, soil, they enter the surface waters or even groundwater together with rain.

Unfortunately, both veterinary and human drugs after their expiration are still disposed of in landfills and enter the environment together with the filtrate from landfills (Plant J. A. et al., 2012) (see Figure 2).

Fertilization of cultivated field with sewage sludge can cause occurance of these substances in the agriculture.

A. et al., 2012; NACWA, 2010).

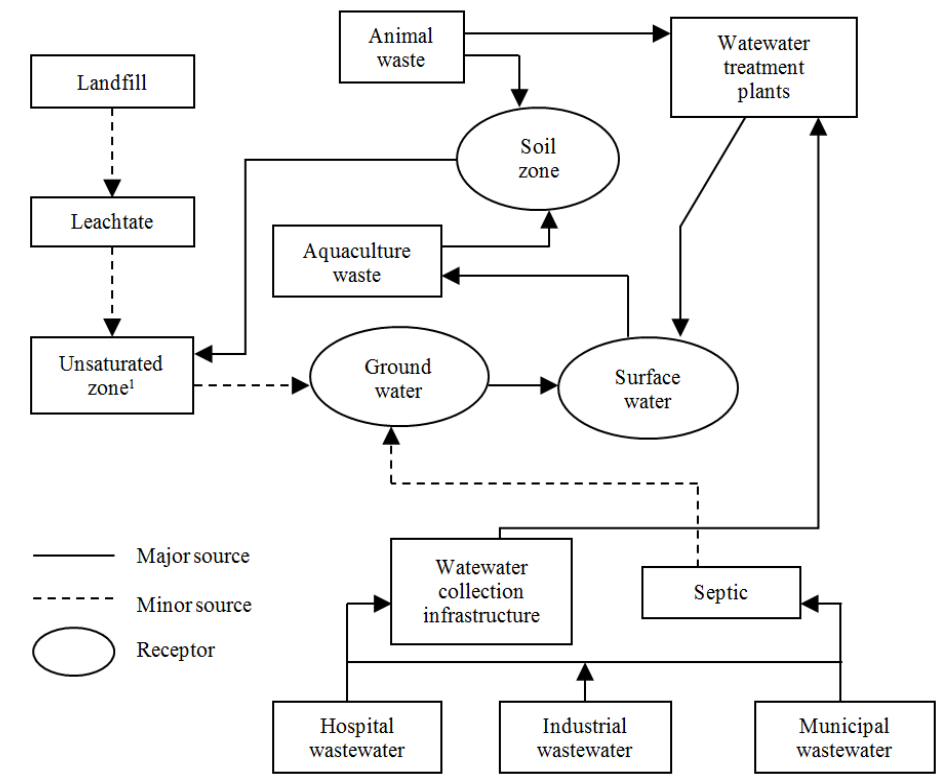

Fig. 2. Main flows of pharmaceutical substances in the environment (applied agreeably to Gao L. et a.l, 2012; Petrovic M. et al., 2003)

where: 1 - The zone of aeration - the underground part that is unsaturated with water.

The scheme above (Fig. 2) presents main flows of pharmaceutical chemical substances outspread in the environment (Gao L. et al., 2012; Petrovic et al., 2003).

Pharmacologically active substances enter the environment through various sources of anthropogenic activities and in various ways. The pharmaceutical substances consumed by humans are excreted from the organism together with urine or faeces, or are thrown directly to sewerage together with wastewater, in most cases they enter the environment after passing waste treatment plants (Wennmalm, 2011).

Prevalence and detection of tested substances in the environment. Tested substances enter drinking water via the aquatic cycle. During the research on drinking water treatment Maria Huerta-Fontela et al. (2011) have found that the untreated drinking water contains $2.5 \mathrm{ng} / \mathrm{l}$ of EE2.

In 1997 Netherlander Belfroid et al. made the analysis of various samples taken from surface water
(11), industrial (2) and household wasterwater (3) and found the concentrations of 17- $\alpha$-estradiol, estrone, tested materials E2 and EE2. The scientists determined that the household wastewater contained the biggest concentrations of hormonal substances. During the winter time the concentrations of tested substances exceeded $6 \mathrm{ng} / \mathrm{l}$, during the autumn time they were lower than determined limits. The concentrations of E2 and estron did not exceed $1 \mathrm{ng} / \mathrm{l}$, in most samples the concentrations of 17- $\alpha$-estradiol, EE2 were lower than the determined ones, i.e. 0.1-1.8 ng/l (Belfroid A. C. et al., 1999).

To analyze the conventional wastewater treatment facilities that meet the legal requirements for waste water treatment up to the fixed norms, comprehensive research was done, however, the results have revealed that conventional treatment technologies are only partially effective in the removal of pharmaceutical substances (Jelic et al., 2011; Gao et al., 2012). Wastewater treatment plants suppress chemical pharmaceutical contaminants, 
whereas the degree of wastewater treatment differs strongly from the same concentrations of contaminants in the treated water up to a high purification degree for different compounds, when the water flow that enters a wastewater treatment plant is compared to the water flow from the plant. For example, Gao L. et al. (2012) have found that the efficiency of antibiotics removal from wastewater is equal to $34-72 \%$ and during the treatment of ordinary household wastewater the efficiency of oestrogen removal fluctuates between 75 and $85 \%$ (DoerrMacEwen N. A., 2007). The findings of the completed scientific research on DCF, E2 and EE2 are presented in Table 4.

Table 4. Concentrations of DCF, E2 and EE2 in inlet and outle wastewater, the efficiency of treatment

\begin{tabular}{|c|c|c|c|c|c|}
\hline $\begin{array}{l}\text { Pharaceutical } \\
\text { substance }\end{array}$ & Country & $\begin{array}{l}\text { In inflowing } \\
\text { wastewater }\end{array}$ & $\begin{array}{l}\text { In outflowing } \\
\text { wastewater }\end{array}$ & $\begin{array}{l}\text { Treatment } \\
\text { efficiency }(\%)\end{array}$ & Literature source \\
\hline \multirow[t]{5}{*}{ Diclofenac } & Germany & $3.02-7.10 \mu \mathrm{g} / 1$ & $2.51-4.70 \mu \mathrm{g} / 1$ & 8 & Heberer T., 2001 \\
\hline & Spain & $<280 \mathrm{ng} / \mathrm{l}$ & $<140 \mathrm{ng} / \mathrm{l}$ & 50 & Santos J. L., 2005 \\
\hline & Austria & $0.905-4.114 \mu \mathrm{g} / 1$ & $0.780-3.434 \mu \mathrm{g} / 1$ & $13.8-16.5$ & Clara M. et al, 2005 \\
\hline & Spain & $0.4-1.5 \mu \mathrm{g} / 1$ & $0.4-1 \mu \mathrm{g} / 1$ & $0-33.3$ & Jelic A. et al, 2011 \\
\hline & Spain & $0.72 \mu \mathrm{g} / 1$ & $0.53 \mu \mathrm{g} / 1$ & 26.4 & Martin J. et al, 2012 \\
\hline \multirow{3}{*}{$\begin{array}{l}\text { 17- } \beta \text {-estradiol } \\
\text { (E2) }\end{array}$} & USA & $14.6 \mathrm{ng} / \mathrm{ml}$ & $2.5 \mathrm{ng} / \mathrm{ml}$ & 82.9 & Snyder S.A. et al, 2001 \\
\hline & USA & $1.9 \mathrm{ng} / \mathrm{ml}$ & NA & $>80$ & Snyder S.A. et al, 2001 \\
\hline & Spain & $0.19 \mu \mathrm{g} / 1$ & $<\mathrm{LOQ}^{0.072}$ & 62.1 & Martin J. et al, 2012 \\
\hline \multirow{2}{*}{$\begin{array}{l}17-\alpha- \\
\text { ethinylestradiol } \\
(E E 2)\end{array}$} & USA & $1.43 \mathrm{ng} / \mathrm{ml}$ & NA & $>70$ & Snyder S.A. et al, 2001 \\
\hline & USA & $\begin{array}{l}0.15 \mu \mathrm{g} / 1 ; \\
0.07 \mu \mathrm{g} / 1 ; \\
0.18 \mu \mathrm{g} / 1\end{array}$ & $\begin{array}{l}0.03 \mu \mathrm{g} / \mathrm{l} ; \\
0.04 \mu \mathrm{g} / \mathrm{l} ; \\
0.18 \mu \mathrm{g} / \mathrm{l} \\
\end{array}$ & $\begin{array}{l}80, \\
42.9, \\
0 \\
\end{array}$ & Martin J. et al, 2012 \\
\hline
\end{tabular}

6. Division of tested substances and their persistence in the environment

Chemical and physical properties of pharmaceutical substances determining their persistence in the environment. The condition of pharmaceutical substances strongly depends on the degree of their attenuation, also on physical and chemical properties, for example, solubility in water (Pal A. et al., 2010). General rule for all substances is as follows: the stronger the acid the lower its $\mathrm{pKa}$ (Bagdoniene L., 2006). Table 5 presents the summarized chemical and physical properties of tested substances

Table 5. Chemical and physical properties of tested substances

\begin{tabular}{||l|l|l|l|l|l|l||}
\hline $\begin{array}{l}\text { Class of } \\
\text { compound and } \\
\text { pharmaceutical } \\
\text { substance }\end{array}$ & $\begin{array}{l}\text { Molecular } \\
\text { formula }\end{array}$ & $\begin{array}{l}\text { Molecular } \\
\text { mass, g/mol }\end{array}$ & Condition/ color & $\begin{array}{l}\text { Vapor } \\
\text { pressure, } \\
\mathbf{m m ~} \mathbf{H g}\left(25^{\circ} \mathrm{C}\right)\end{array}$ & $\mathbf{p} \boldsymbol{K}_{\mathbf{a}}$ & $\mathbf{L o g} \boldsymbol{K}_{\boldsymbol{o w}}$ \\
\hline $\mathrm{DCF}$ & $\mathrm{C}_{14} \mathrm{H}_{11} \mathrm{Cl}_{2} \mathrm{NO}_{2}$ & 296.1 & $\begin{array}{l}\text { Crystalline solid } \\
\text { substance }\end{array}$ & $6.14 \times 10^{-8}$ & 4.15 & 4.51 \\
\hline $\mathrm{E} 2$ & $\mathrm{C}_{18} \mathrm{H}_{24} \mathrm{O}_{2}$ & 272.4 & $\begin{array}{l}\text { White odorless } \\
\text { crystalline powder }\end{array}$ & $6.38 \times 10^{-9}$ & 10.4 & $3.9-4.0$ \\
\hline $\mathrm{EE} 2$ & $\mathrm{C}_{20} \mathrm{H}_{24} \mathrm{O}_{2}$ & 296.4 & $\begin{array}{l}\text { Fine white odorless } \\
\text { crystalline powder }\end{array}$ & $1.9 \times 10^{-9}$ & $\begin{array}{l}10.4- \\
10.7\end{array}$ & 3.67 \\
\hline
\end{tabular}

Information sources: databases of the programs MPBPVP (v1.43) and ECOSAR (v1.11) (EPI Suite, 2012); Carballa M. et al., 2008.

Having entered the environment air, due to its physical properties DCF (under the vapor pressure indicated in Table 4) will exist both in the form of vapor and in particles. pKa 4.15 indicates that almost all the time DCF will be in the ionic form (anion), when $\mathrm{pH}$ is 5-9. For this reason volatility of this substance is not recognized as one of the most important decomposition processes in the environment. E2 and EE2 are nonvolatile, too, in the air of the environment they are exclusively found only in the form of particles (PubChem, 2014).

Carboxylic acids and neutral pharmaceutical substances usually have smaller coefficients of sorption when compared to amines, this is due to the lower organic composition. The substances of bigger molecular mass with $\log \mathrm{K}_{\mathrm{ow}}>5$ are more easily absorbed in the residues and are removed with coagulants (Pal A. et al, 2010). Contrarily, the compounds with $\log \mathrm{K}_{\mathrm{ow}}<2.5$ are characterized by low properties of sorption and can easily remain in the surface water or the soil zone (Mompelat et al., 2009). For example, $\log \mathrm{K}_{\mathrm{ow}}$ of diclofenac is higher than 4 , thus, it can be efficiently removed during the process of active sludge absorption (Li W. C., 2014). However, during some research the controversial results were obtained, although both inflowing and outflowing wastewater contained small amounts of diclofenac, the residuals of this pharmaceutical substance were not detected in the sludge (Martin J., 2012).

Metabolism and excretion of tested substances. Diclofenac consumed orally by patients is the usual form of drugs that represents about $70 \%$ of diclofenac sold all over the world (Zhang Y. et al, 2008). Liquid diclofenac is more popular in economically developed countries and this form of the drug is more beneficial, 
because it reduces bioaccesibility and biotransformation in the liver up to $50 \%$, therefore bigger amounts of active diclofenac can enter the aquatic environment (Zhang Y. et al, 2008). Diclofenac itself decomposes in human organism. This substance usually enters the aquatic environment together with urine in the form of glucuronides and sulfates conjugates (apprx. 65\%), 35\% of it remains in the gall (Plant J. A et al., 2012). The mass balance (\%) of orally consumed diclofenac and the metabolites in the wastewater determined by Zhang (2008) are presented in Figure 3.

FEACES

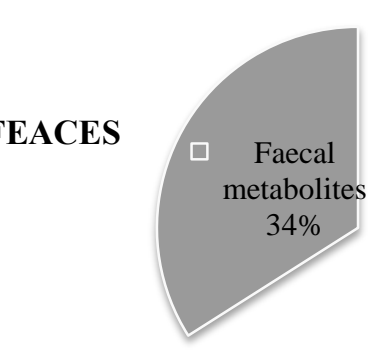

- Diklofenac

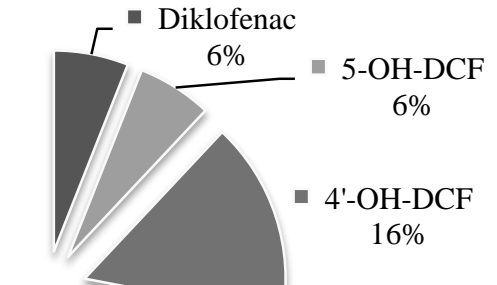

URINE

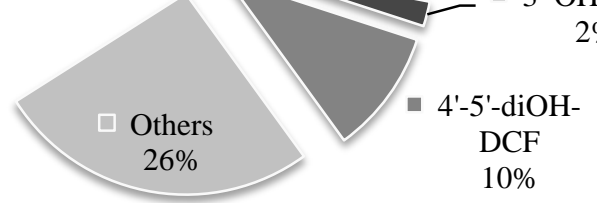

Fig. 3. Forms of metabolites of orally consumed DCF (Zhang et al., 2008)

Hormonal pharmaceutical substances are usually consumed orally, too. When they decompose, $54 \%$ of active EE2 found in the human organism enters the wastewater together with urine, $6 \%$ of the substance enters the wastewater together with faeces (Speck U., 1976), the rates of E2 entering the wastewater are $38 \%$ and $62 \%$, respectively (Dusterberg B. et al, 1982). It is worth mentioning that the degree of hormons excretion varies and depends on the group of people consuming these hormonal substances or naturally producing them.

Significant part of E2 is excreted in the gall, which is recognized as location of enterohepatic recirculation of oestrogen metabolites, oestrogens are hydrolyzed and reabsorbed in the gall, thus biological absorption of the substance and its further excretion from the organism proceeds together with urine. In fact, these active substances split into glucuronides and sulphatic oestrogens: Estrone (E) (13\% -30\%), 2hydroxy-E $(2.6 \%-10.1 \%)$, E2 $(5.2 \%-7.5 \%)$, and $16-$
$\alpha$-hydroxy-E (1.0\% -2.9\%) (Frank Z., 2013), and glucuronides are considered to be the main metabolic compounds. Conjugated oestrogens are characterized by their stronger property of solubility in water, therefore their mobility in the aquatic environment becomes stronger and higher. Actually, estrogen conjugates do not act as oestrogens because they can not connect with the oestrogen receptors, however their hydrolisis (i.e. deconjugation) can occur and they can turn into free oestrogens.

\section{Removal of pharmaceutical substances from wastewater}

Traditional wastewater treatment. Primary precipitation and technologies of active sludge are considered to be the most widespread method of water treatment and it is applied in Lithuania. Its general scheme is presented in Figure 4.

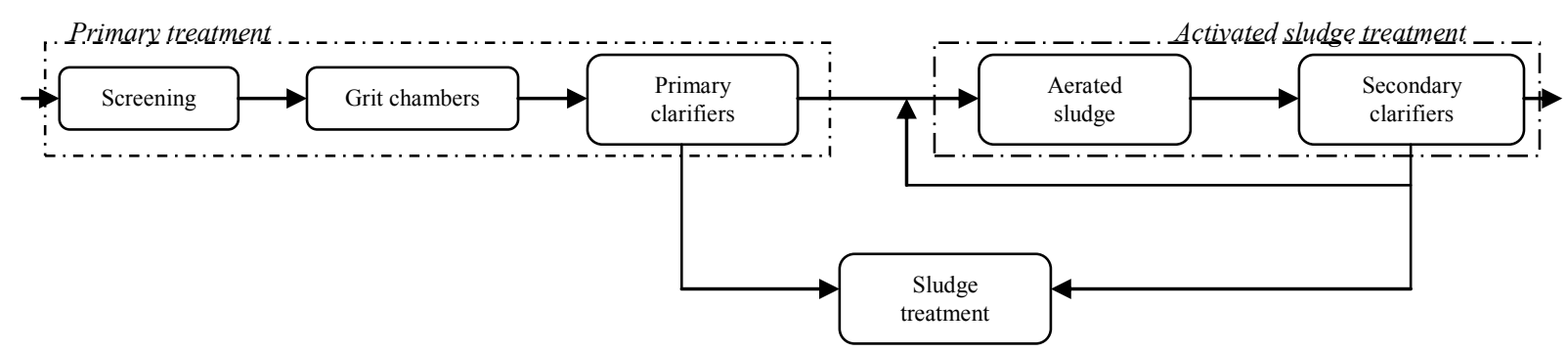

Fig. 4. Traditional technological scheme of wastewater treatment

Traditional wastewater treatment plants not used for removing biodegradable organic chemicals are found to be quite effective in dealing with most but not all pharmaceutical substances (NACWA, 2010). N. Paxéus (2004) has found that very low amounts of neutral carbamazepine or atenolol, also metropolol and trimethoprim $(<10 \%)$ are removed from wastewater treated with active sludge.
In removing pharmaceutical substances from the active sludge and in the processes of removal of biological substances continuance time of hard particles $(S R T)$ is to be taken into account. It is argued that this parameter influences the evelopment of biological communities, which have the potential to degrade chemical compounds, whereas this factor determines degradation efficiency (NACWA, 2010). 
Effectiveness of chemical compounds degradation strongly differs, depending on their physico-chemical properties, and it is not always possible to define precisely the duration of hard particles suppression. When studying the efficiency of pharmaceutical substances removal from the wastewater depending on SRT, Clara et al. (2005) have determined that the efficiency of diclofenac removal during the whole period of 275 days strongly varied, whereas the efficiency average was $60 \%$, however they failed to determine the correlation between SRT and treatment efficiency. When Zhou et al (2013) were testing the absorbtion of biological sludge of wastewater treatment plants of pharmaceutical substances, including diclofenac, they have determined that under thermophilic conditions and when SRT is 6 days the efficiency of diclofenac removal from the wastewater is equal to $72 \%$, whereas the removal efficiency under mesophilic anaerobic conditions and when SRT lasts 10 days it increases up to $75 \%$. Mesophilic conditions are more effective with other pharmaceutical substances, they have allowed researchers to achieve $99 \%$ of efficiency.

It is worth mentioning that in most cases "removal" of more hydrophobic and persistent pharmaceutical substances means that the compounds are removed from the aquatic phase and they accumulate in the solid phase, e.g. sewage sludge (NACWA, 2010). Martin J. et al (2012) have determined that sludge absorbtion with pharmaceutical substances is one of the main factors that must be considered in order to manage the removal of chemical pharmaceutical substances from wastewater. While testing the wastewater in the liquid phase they have detected DCF, E2 and EE2, whereas they have detected only hormonal substances in the sludge.

Wastewater collection systems in Europe and Lithuania. On the basis of the data of the seventh Directive of 2013 on the Urban Waste Water Treatment (91/271/EEC) implementation report, it is known that the level of wastewater collection in many EU countries is very high, i.e. the average level of compliance is equal to $94 \%$. The level of compliance of approximately 15 Member states is equal to $100 \%$. The previous results were either the same or were improved in all Member states. However, there are the countries that demonstrate zero collection of wastewater, or it is collected just partially. The level of compliance in five Member states (Belgium, Cyprus, Estonia, Latvia, Slovenia) was less than $30 \%$ during 2009 -2010.

The secondary treatment. During the period of 2009- 2010 the secondary treatment corresponding to the provisions of the Directive was applied to $82 \%$ of the EU wastewaters. The results that were compared to the previous report have improved by $4 \%$. The requirements were fully implemented by $100 \%$ in four Member states, whereas in six Member states the requirements were implemented by $97 \%$ and more. Nvertheless, the level of compliance in Member states EU-12 is much lower, i.e. the proper secondary treatment is applied to only $39 \%$ of wastewater. Only in Czechia, Hungary, Lithuania and Slovakia the results of compliance are equal to $80-100 \%$.

The tertiary treatment. This type of wastewater treatment, known as the tertiary treatment, supplements the secondary treatment when necessary, it is mainly intended for the removal of nutrients in the battle against eutrophication or in reduction of bacteriological pollution that can influence human health (e.g. affect the zones of drinking water or bathing water). The total level of compliance was $77 \%$. Regrettably, implementation of stricter wastewater treatment was significantly delayed in Member states EU-12, which is characterized by only $14 \%$ of properly treated wastewater. On the positive side it should be noted that four countries achieved $100 \%$ of compliance (COM (2013) 574).

Lithuania is among 10 countries which comply with the Directive of Urban Waste Water Treatment in the best manner. The total evaluation of wastewater collection and treatment systems is eqaul to $100 \%$, the evaluation of the secondary treatment of wastewater is equal to $>95 \%$ and the evaluation of the tertiary treatment of wastewater is equal to $>85 \%$.

\section{Management of pharmaeutical substance waste}

Drugs are consumed either by various people or veterinary activity and in spite of it a lot of pharmaceutical preparations are disposed of unused. Drugs with expired validity, improperly produced or used drugs, some inadvertently used or not used drugs are disposed of without reaching their target. Veterinary industry, the industry of human drugs and households are obvious polluters of pharmaceutical substances in the environment. Various studies have indicated that the majority of unused medications are disposed of together with household waste or are outpoured into sewarage. The annual quantity of sold drugs was evaluated in Germany (16 000 tons of drugs), also the research on drugs consumption by residents has revealed that $60-80 \%$ of all acquired preparations are outpoured either to sewer networks or disposed of together with municipal waste (Scheytt T. J., 2006). Bound and Voulvoulis (2005) analyzed the disposal of unused and expired medical preparations from households. 400 respodents in Great Britain participated in the special survey which has shown that approximately half of the respondents have not used the acquired drugs before their expiration and $63.2 \%$ of them disposed of the unused preparations together with municipal waste, $21.8 \%$ have returned them back to the pharmacy, whereas $15 \%$ have outpoured them to the sink or toilet.

The waste disposed in the landfills accumulates over the time and, depending on environmental conditions, begins to disintegrate and eventually together with the landfill filtrate penetrates into the surface and ground water. The concentration of pharmaceutical substances found in the landfills can be very high. In the analysis performed in the USA on 
more than $2,000 \mathrm{~kg}$ of solid municipal waste taken from the landfill (coresponding to $8.1 \mathrm{mg} / \mathrm{kg}$ of solid waste) $22,910 \mathrm{mg}$ (22.9 g) of 22 different sorts of drugs were found there (Musson ir Townsend, 2009). If in the landfills there is no filtrate collection system or it is affected, the filtrate escape can occur which can cause pollution of the soil, groundwater and surface water.

Management of pharmaceutical waste in Lithuania. In accordance with the existing procedure of waste management, residents can bring the expired drugs to community pharmacies or drug production plants without paying for this service. The survey of Lithuanian citizens (2007) revealed that the majority of the respondents dispose of outdated and unwanted drugs together with household waste. Such behavior is typical among $89 \%$ of the urban population, $87 \%$ of the suburban and town residents and $50 \%$ of the residents of rural areas; the lack of information is recognized as the main reason of this phenomenon, i.e. residents do not return the outdated and unwanted drugs to pharmacies (Kruopiene J. and Dvarioniene J., 2007). The drugs no longer appropriate for use are brought to pharmacies which decontaminate them.

The following processing technologies of decontamination are applied by Lithuanian Health Care Facilities: vapor sterilizers (autoclaves), microwaves, disinfect chemicals (biocides) and the others (the report of the Chancery of the Government of the Republic of Lithuania, 2010).

In 2009 the biggest amount of pharmaceutical waste was decontaminated using microwaves (305 tons). After decontamination pharmacies pass the waste to hazardous waste treatment operators which are appointed by the Ministry of Environment of the Republic of Lithuania in accordance with the established procedure of procurement (No. 12-047901-N). Waste treatment operators (companies) apply the methods of decontaminated waste disposal, i.e. incineration and burial (the report of the Chancery of the Government of the Republic of Lithuania, 2010).

In $200998 \%$ of medical waste (containing $100 \%$ of pharmaceutical waste) was incinerated (the report of the Chancery of the Government of the Republic of Lithuania, 2010). This method of disposal is economically advantageous only for the country's major hospitals which generate the biggest amount of pharmaceutical waste. The procedure and payment for the services of waste management is determined by the Government or its authorized institution, i.e. the Ministry of Health. Broadly speaking, the system of pharmaceutical waste management has not been developed yet and many limitations are found in the system, especially administrative ones (the report of the Chancery of the Government of the Republic of Lithuania, 2010). Funding of the medical waste management in health care facilities is also insufficient (resolution No. 1224, 2007 of the Government of the Republic of Lithuania), therefore economically favorable way of waste management is applied which is not favorable environmentally.

Among the planned waste management strategic objectives the following task for the period of 2014 -
2020 is provided in the plan of Lithuanian waste management of 2013: improvement of the system of medical and pharmaceutical waste management. There is evidence that appropriate actions are already in progress to move towards the correct direction, namely, in autumn of 2013 new requirements for medical waste and temporary storage in the health care facilities became effective - HN 66:2013 "The requirements for the medical waste management and safety". The law requires confirmation of the procedure of medical waste management in medical care facilities; the procedure states that the groups of medical waste are generated during the activity of the facility; also the information about the procedure of this waste management starting from the waste collection until its passing to the waste treatment operator must be presented. Since 2012 the amount of collected unused drugs increased by $99 \%$ compared to the year 2011, i.e. 11,687 t (see Figure 7), this is the result of more strict administration of medical waste. When the requirements became stricter, all the medical care facilities with more than 10 employees began to carry out the accounting of such waste and stopped presenting reports to the Ministry of Environment.

The amounts of pharmaceutical waste in Lithuania. In accordance with the data of the Environmental Protection Agency during the period of 2008-2010 the amounts of medical waste (only the waste corresponding to code 18 was evaluated) have increased by $47.1 \%$, and since 2011 these amounts have decreased by $23.5 \%$. In accordance with the same data the majority of pharmaceutical waste, i.e. 0.067 tons, was exported to Germany to be incinerated in the specialized hazardous waste incinerators (the LRVK project, 2010).

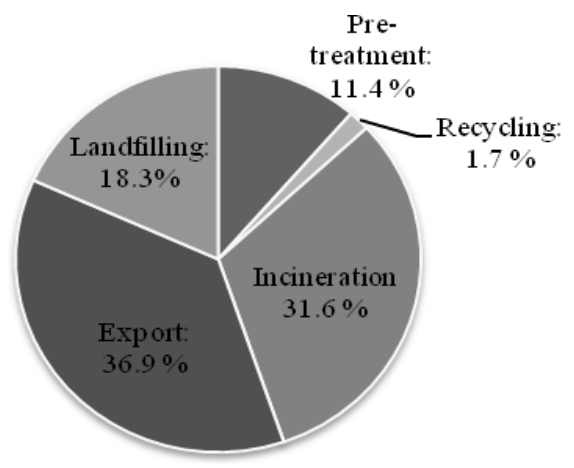

Fig. 5. Collection of medical waste in accordance with the method of disposal in 2011 (expressed in percentage) (Lithuanian EPA database, 2011)

During the period of 2008 - 2011 in the total amount of medical waste the part of unused drugs was equal to 0.5 and $5 \%$. Broadly speaking, although the amount of medical waste has decreased in 2011 , the amount of unused drugs was bigger by $20.3 \%$, the amount of unused drugs per 100 thousand residents was also increasing. It is supposed that thse changes have been caused by improvements in the drug collection and administration system. 
- Unused medicines quantity per 100 thousand residents, $\mathrm{kg} / 100$ thousand residents

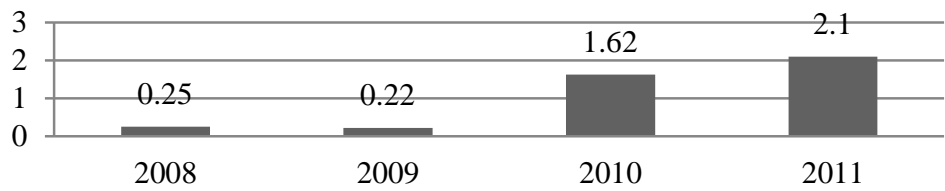

Fig. 6. The amount of unused drugs in Lithuania during the period between 2008 and 2011 (Lithuanian EPA database, 2008-2011)

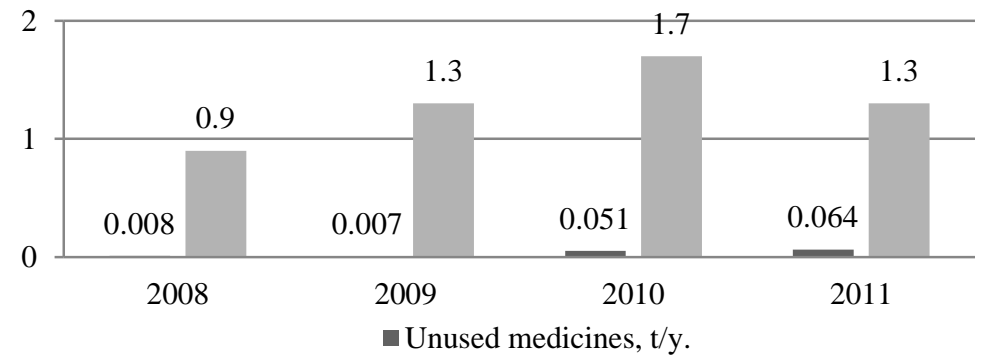

Fig. 7. The amount of medical waste in Lithuania during the period of 2008-2011 (Lithuanian EPA database, 2008-2011)

\section{Consumption of DCF, E2 and EE2 drugs in Lithuania}

Lithuanian pharmaceutical industry. At the beginning of 201420 economic subjects were manufacturing pharmaceutical preparations and products in Lithuanian drug industry (Statistics Lithuania, 2014). The number is not big compared to the numbers of other subjects in the sector of manufacture or chemistry and chemicals production. The majority of companies are involved in the activity of drugs import, their packing, prepacking and sales, and only small part is involved in the activity of drugs production. The main manufactured products are as follows: natural drugs, supplements, herbal products, beekeeping products. The other group of manufactured products consists of biopharmaceuticals (UAB "Sicor Biotech"), final forms of drugs (AB "Sanitas", UAB "Aconitum"). According to the opinion of the specialists of the State Medicines Control Agency (SMCA) pharmaceutical substances DCF, E2 and EE2 are not manufactured.

Consumption of the tested substances in Lithuania. In the period of 2009 - 2014 the demand for drugs kept on growing, and last year the positive change was reported, i.e. by $4.12 \%$ (see Figure 7 ).

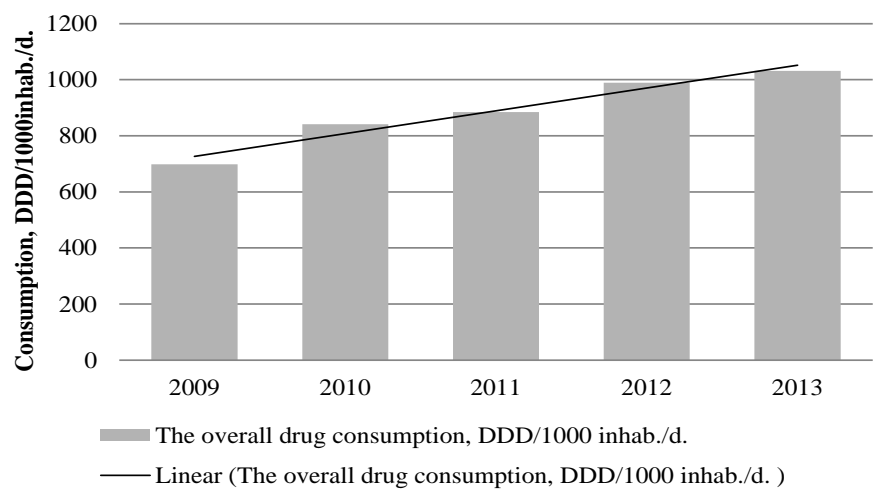

Fig. 8. Data of medical preparations consumption in Lithuania during 2009-2013 (VVKT report, 2013)

In fact the number of the packages of sold medical preparations presented by the companies of wholesale distribution does not reflect by $100 \%$ the real number of the drugs consumed, since the drugs can still be in the pharmacies, hospitals or homes. However, even taking into account the abovementioned statement DDD provides informative facts about the consumption of drugs in Lithuania (SMCA, 2014).

During 2009 - 2013 the demand for drugs that affect the musculoskeletal system has increased by $4.9 \%$, the demand for drugs that affect the urogenital system and sex hormones has increased by $9.85 \%$. The sales of diclofenac were equal to $30.3 \%$ of all the sales in accordance with ATC subgroup, the sales of estradiol and ethinyl estradiol in their subgroup were equal to 47.3 and $11.6 \%$, respectively (see Table 6). The comparison of the consumption of the medical preparations of both subgroups reveals that the consumption of the drugs that affect the urogenital system was equal only to one third of the consumption of 2010. The consumption of the tested pharmaceutical substances has increased during the 
last year and hopefully the increase in consumption of

these substances will be observed in the future, too.

Table 6. Sales of the tested substances in Lithuania during 2009-2013 (VVKT report, 2013)

\begin{tabular}{||r|c|c|c|c|c|c|c||}
\hline \hline \multirow{2}{*}{$\begin{array}{l}\text { The group of medical preparations/ } \\
\text { Active substance }\end{array}$} & \multicolumn{5}{|c|}{ DDD /1000 Lithuania inhab./d. } & Relative \\
change, \% & $\begin{array}{l}\text { The amount of } \\
\text { the tested } \\
\text { substance*, \% }\end{array}$ \\
\cline { 2 - 9 } & $\mathbf{2 0 0 9}$ & $\mathbf{2 0 1 0}$ & $\mathbf{2 0 1 1}$ & $\mathbf{2 0 1 2}$ & $\mathbf{2 0 1 3}$ & - \\
\hline $\begin{array}{r}\text { Drugs that affect the musculoskeletal } \\
\text { system }\end{array}$ & 56.8 & 59.4 & 66.1 & 69.3 & 72.4 & $4.42 \uparrow$ & 30.3 \\
\hline Diclofenac & 20.52 & 19.56 & 19.76 & 21.26 & 21.91 & $3.05 \uparrow$ & - \\
\hline $\begin{array}{r}\text { Drugs that affect the urogenital } \\
\text { system }\end{array}$ & 9.65 & 28.79 & 27.37 & 30.07 & 29.59 & $-1.61 \downarrow$ & 47.3 \\
\hline Estradiol & 0 & 15.52 & 14.92 & 15.07 & 13.98 & $-7.23 \downarrow$ & 11.6 \\
\hline Ethinelestradiol & 0.54 & 1.35 & 1.40 & 1.52 & 1.62 & $6.24 \uparrow$ & - \\
\hline
\end{tabular}

*the amount of the tested substance consumed in 2013 is determined in accordance with the amount of the main group of the medical preparations of the tested active substance, $\%$

According to the data of the State Medicines Control Agency diclofenac was the sixth in the list of the mainly consumed drugs during 2013 in accordance with their generic name. Urologic drugs are also among widely consumed medical preparations, and in 2012 their sales have increased by $27 \%$.

Consumption of DCF, E2 and EE2 in three Baltic States. In Estonia, Latvia and Lithuania DCF is among the most popular medical preparations. In accordance with the statistics of the medical preparation consumption in the Baltic States presented by the State Medicines Control Agency, $\mathrm{DFC}$ is the $12^{\text {th }}$ among the mainly consumed substances in Estonia, in Latvia it is the $3^{\text {rd }}$ and in Lithuania it is the $5^{\text {th }}$. According to the extent of the medical preparations consumption, Latvia sells the biggest amounts of DCF, the second is Lithuania, however the comparison of the sold amount of the products per 1000 residents of the country reveals that Lithuania is in the last position, consumption per 1000 residents is approx. lower twice (see Table 7).

Table 7. The amount of DCF consumption in three Baltic States and the amount of the substances per 1000 residents during the years 2011 and 2012 (Baltic Statistics on Medicines 2010-2012)

\begin{tabular}{|c|c|c|c|c|c|}
\hline \multirow{2}{*}{\multicolumn{2}{|c|}{$\begin{array}{l}\text { DCF / combinations } \\
\text { with DCF }\end{array}$}} & 2010 & 2011 & 2012 & \multirow{2}{*}{$\begin{array}{c}\text { Consumption (DDD/1000 inhab./d.) } \\
\text { per } 1000 \text { capita, } 2012\end{array}$} \\
\hline & & \multicolumn{3}{|c|}{ Consumption, DDD/1000 inhab./d. } & \\
\hline \multirow{3}{*}{$\begin{array}{l}\stackrel{\vec{E}}{\Xi} \\
\stackrel{\Xi}{0}\end{array}$} & Lithuania & $18.836 / 0.73$ & $19.027 / 0.73$ & $20.494 / 0.77$ & 0.0068 \\
\hline & Latvia & $21.48 / 1.77$ & $22.19 / 1.83$ & $23.85 / 1.80$ & 0.0118 \\
\hline & Estonia & $13.12 / 0.08$ & $13.09 / 0.07$ & $13.12 / 0.06$ & 0.0102 \\
\hline
\end{tabular}

Information source: State Medicines Control Agency of Lithuania

Consumption of hormonal substances in all three states differs strongly; consumption of some active substances is higher, whereas consuption of other substances is significantly lower; consumption of some substances is approximately equal in all countries. Therefore, it is quite difficult to make a comparison here, and it is supposed that it can be dependant on some changes in the market, the particular socio-cultural indicators. Relatively, Lithuania is not the country of the Baltic region that consumes the biggest amount of medical preparations, however here the size of the state's population remains an important factor that mostly influences the indicator of the general consumption of the country and the general extent of generated pollution.

Veterinary drugs containing DCF, E2 and EE2. The Lithuanian State Food and Veterinary Service (hereinafter referred to as SFVS) acts in accordance with the principle of confidentiality and does not publish the data which may be related to the disclosure of business secrets (in this case, the amounts of particular veterinary drugs that can be found in the market of the Republic of Lithuania). Moreover, the data base of Register of Veterinary Drugs, wchich is public available in the website of State Food and Veterinary Service, does not contain the information on veterinary drugs with the active substances of DCF, E2 and EE2. This indicates that veterinary with these substances are not registered and are unauthorized in the Republic of Lithuania, therefore these veterinary drugs can not be used for veterinary purposes. However, as it was mentioned above, the cases of exceeded diclofenac maximum allowable concentration in the farm animal meat are detected each year. It is assumed that farm animals are treated with human drugs, and due to the inability to control this activity the appropriate legal act was adopted that regulates DCF concentration in the cattle and pig meat. Due to these faults the assessment of veterinary drugs prevalence in the environment is very complicated, but without any doubt its evaluation is essential. Hopefully, the problem of diclofenac used for veterinary purposes will become the publicly discussed issue in Lithuania in future.

\section{Discussion}

When checking the animal meat, at least several cases are traced with an increase in DCF concentration over the maximum allowable limit in $\mu \mathrm{g} / \mathrm{kg}$ by several times. So far diclofenac is not registered in the the Register of Veterinary Drugs of the Republic of Lituania and this substance does not 
exist in the market of veterinary drugs. It is believed that human drugs are used for the treatment of animals.

Due to very small concentrations of the tested pharmaceutical substances $(\mathrm{ng} / \mathrm{l}, \mu \mathrm{g} / \mathrm{l})$ that can be found in the drinking water, the probability of the risk to human health is potentially low, since the dose of substances determined as an active therapeutic dose can be higher up to one million and more times. Nevertheless, the question of a long-term and synergistic effect of several pharmaceutical substances entering our organism together with drinking water remains unanswered. It is likely that due to the chronical effect of the substances the organism will become resistant to them and when the effect of drugs is needed they are of no help.

Management of pharmaceutical substances in the aqautic environment can be carried out at several levels -from local to international. Large scale management, e.g. at the international, national or district level bears an importance because of development and funding of the regulation of the substances management both for the development of management and development of pharmaceutical substances. Actually, the highest concentrations of pharmaceutical substances are found in densely populated urban areas and especially in the flows of domestic wastewater that access the wastewater treatment plants located in different municipalities. The flows of wastewater from hospitals and laboratories where the concentrations in wastewater are much bigger compared to those in domestic wastewater are also considered important. Therefore, wastewater treatment plants should play an important role in the management of the escapes of pharmaceutical substances into the environment and they can significantly contribute to the development of the measures of reduction and management of pharmaceutical pollutants in the environment.

This analysis has revealed the fact that the presence of DCF, E2 and EE2 in the environment is a very relevant problem all over the world, whereas in Lithuania it is a new and unexplored sphere. Due to the risk aspects discussed above, the mentioned substances should be measured, especially in wastewater, surface water, sea coastal water, and the actual amount of these substances in the environment should be determined. It is likely that legal requirements for pharmaceutical substances in the environment will become stricter. If the substances discussed in this work will be included in the list of priority substances, the mandatory monitoring shall be performed and the maximum allowable concentrations of these substances shall be determined in the aquatic environment while wastewater treatment plants should be capable to remove them from wasterwater. Preconcern would be beneficial in anticipating and preparing strategically for these challenges. Preventive intentional measures could help those concerned to achieve the environmentally effective results even, for example, interrupting in the substances' escape into the environment.

\section{Conclusions}

- In Lithuania the pharmaceutical substances DCF, E2 and EE2 are subject to the requirements of waste management, DCF concentrations in the food of animal origin are regulated, direct provisions for priority substances in the field of aquatic policy and average annual quality standards determined by the Eurolean Commission (VM-AKS, ng/1) are applied.

- In Lithuanian Veterinary market there are no drugs containing active substances in tested DCF, E2 and EE2, however the DCF concentrations are regulated for the food products of animal origin.

- $\quad$ Analysis of Directive 2013/39/EU has indicated that the period of the monitoring of the tested substances in the aquatic environment should begin in Member states before the end of 2015, 4 presentable monitoring stations should be selected for this purpose.

- The amounts of tested substances found in the drinking water due to their concentrations by several times lower than the daily therapeutic dose (ng/l) have no effect on human health, however long-term and synergistic effect of multiple drug combination has not been determined. Whereas the dose that is lower than $0.1 \mathrm{ng} / \mathrm{l}$ can affect the organisms which live in the natural ecosystems. Biota and the organisms which live in biota are recognized as the most sensitive subjects for tested substances.

- Excretion is recogniszed as the main way of tested substances' penetration to the environment. Apprx. 65\% of DCF, apprx. $63 \%$ of E2 and apprx. $57 \%$ of EE2 enter the environment.

- Technologies of active sludge are the main method of wastewater treatment in Lithuania. Lithuania is among 10 countries of the EU which have achieved the best results in the field of wastewater treatment, whilst $23 \%$ of Lithuanian residents are till recognized as figures $\mathrm{X}$ in the field of wastewater treatment.

- Lithuanian system of pharmaceutical substances waste management is characterized by visible positive changes. In 2011 the amount of medical waste decreased by $23.5 \%$, during 2008-2011 the amount of collected unused drugs per 100 000 residents increased by $88.1 \%$, while disposal in the landfill is still very popular both in health care facilities and among the residents.

- The statistical analysis of drugs consumption shows that the sales amounts of the tested substances have increased during the last year, diclofenac being the $7^{\text {th }}$ among the most popular drugs in Lithuania in 2013. Since 2009 
consumption of diclofenac has increased by $6.4 \%$. It is likely that the growth of consumption of these substances will be continue.

\section{References}

2009 m. gruodžio 22 d. Komisijos reglamentas (ES) Nr. 37/2010 dèl farmakologiškai aktyvių medžiagų, jų klasifikacijos ir didžiausios leidžiamosios koncentracijos gyvūniniuose maisto produktuose (OL L 15, 20101 20, p. $1-72)$;

2010-2012 m. vaistų suvartojimo Baltijos valstybėse statistika (EN: Baltic Statistics on Medicines 2010-2012), ataskaita anglu kalba. VVKT. Online at: http://www.ravimiamet.ee/sites/default/files/documents/pub lications/baltic_statistics_on_medicines_2010_2012/\#/0;

Bagdonienė L., Bendikienè V., Kadziauskas J., Labeikytė D., Markuckas A., Sabaliauskienè V., Sasnauskienè Z., Deputienè V. (2006), Biochemistry laboratory works, Vilnius University, Department of Biochemistry and Biophysics;

Belfroid A. C., Van der Horst A., Vethaak A. D. ir kt. (2009), Analysis and occurrence of estrogenic hormones and their glucuronids in surface water and waste water in the Netherlands. Science of the Total Environment, 225:101-108; http://dx.doi.org/10.1016/S00489697(98)00336-2;

Bound J. P., Voulvoulis N. (2005), Household disposal of pharmaceuticals as a pathway for aquatic contamination in the United Kingdom, Environ. Health Perspect., No. 113, p. 1705-1711; http://dx.doi.org/10.1289/ehp.8315;

Carballa M., Fink G., Omila F., Lema J.M., Ternes T. (2008), Determination of the solid-water distribution coefficient $\left(\mathrm{K}_{\mathrm{d}}\right)$ for pharmaceuticals, estrogens and musk fragrances in digested sludge, Water Research, No. 42, p. 287-295; http://dx.doi.org/10.1016/j.watres.2007.07.012;

Carlsson C., Johansson A. K., Alvan G., Bergman K., Kuhler T. (2006), Are pharmaceuticals potent environmental pollutants? Part I: environmental risk assessments of selected active pharmaceutical ingredients, Science of Total Environment, No. 364, p. 67-87; http://dx.doi.org/10.1016/j.scitotenv.2005.06.035;

Clara M., Strenn B., Gans O., Martinez E., Kreuzinger N., Kroiss H. (2005). Removal of selected pharmaceuticals, fragrances and endocrine disrupting compounds in a membrane bioreactor and conventional wastewater treatment plants, Water Research, No. 39, p. 4797-4807; http://dx.doi.org/10.1016/j.watres.2005.09.015;

Doerr-MacEwen A. N. (2007), The Management of Human Pharmaceuticals in the Environment, University of Waterloo, PhD thesis, Waterloo, Ontario, Canada, 2007;

Dusterberg B., Nishino Y. (1982), Pharmacokinetic and pharmacological features of oestradiol valerate, Maturitas, No. 4, p. 315-324; http://dx.doi.org/10.1016/0378-5122(82)90064-0;
EPI Suite software database. Online at: http://www.srcinc.com/what-we-do/environmental/toolsand-models.html;

Frank Z. Stanczyk David F. Archer Bhagu R. Bhavnani (2013), Ethinyl estradiol and 17ß-estradiol in combined oral contraceptives: pharmacokinetics, pharmacodynamics and risk assessment, Contraception, No. 87 (6), p. 706-727; http://dx.doi.org/10.1016/j.contraception.2012.12.011;

Gao L., Shi Y., Li W., Niu H., Liu J., Cai Y. (2012), Occurrence of Antibiotics in Eight Sewage Treatment Plants in Beijing, China, Chemosphere, No. 86, p. 665-671; http://dx.doi.org/10.1016/j.chemosphere.2011.11.019;

Gedvilaitė D. (2013), Lietuvos žaliavinio pieno užteršimo A grupès farmakologiškai aktyviomis medžiagomis stebèsenos $2005-2011 \mathrm{~m}$. analizè, Master's thesis, Lithuanian University of Health Sciences, Veterinary Academy, Kaunas;

Heberer T., Verstraeten I.M., Meyer M.T., Mechlinski A., Reddersen K. (2001). Occurance and fate of pharmaceuticals during bank filtration preliminary results from investigation in Germany and the United States. Water Research, Nr. 120, psl. 4-17;

HELCOM activities report (2013), Baltic Sea Environment roceedings No 144. Online at: http://helcom.fi/Lists/Publications/BSEP144.pdf;

HELCOM oficialus puslapis, skiltis HELCOM Core Set Indicators. Online at: http://helcom.fi/helcom-atwork/projects/completed-projects/coreset;

Hoeger B., Kollner B., Dietrich D. R., Hitzfeld B. (2005), Water-borne diclofenac affects kidney and gill integrity and selected immune parameters in brown trout (Salmo truttaf. fario); Aquat Toxicol, No. 75, p. 53-64; http://dx.doi.org/10.1016/j.aquatox.2005.07.006;

Huerta-Fontela M., Galceran M. T., Ventura F. (2011), Occurrence and removal of pharmaceuticals and hormones through drinking water treatment, Water Research, No. 45(3), p. $\quad$ 1432-1442; http://dx.doi.org/10.1016/j.watres.2010.10.036;

Jelic A., Meritxell G., Antoni G., Raquel CespedesSa'nchez, Francesc V., Mira P., Damia B. (2011), Occurrence, partition and removal of pharmaceuticals in sewage water and sludge during wastewater treatment, Water research, No. 45, p. 1165-1176; http://dx.doi.org/10.1016/j.watres.2010.11.010;

Jūrininių tyrimų konsorciumas (JTK), Lietuvos Baltijos Jūros Aplinkos Apsaugos Valdymo Stiprinimo Dokumentų Parengimas II - oji Tarpinè Ataskaita, Klaipeda, 2012;

Jūrininių tyrimų konsorciumas (JTK), Lietuvos Baltijos Jūros Aplinkos Apsaugos Valdymo Stiprinimo Dokumentų Parengimas V - oji Tarpinè Ataskaita, Klaipeda, 2013;

Komisijos Ataskaita Europos Parlamentui, Tarybai, Europos Ekonomikos Ir Socialinių Reikalu Komitetui Ir Regionų Komitetui. Septintoji Miesto nuotekų valymo direktyvos (91/271/EEB) igyvendinimo ataskaita, Briuselis, $20130807 \mathrm{COM}(2013)$ 574. Internete: 
http://eur-

lex.europa.eu/LexUriServ/LexUriServ.do?uri=COM:2013:0

574:FIN:LT:PDF;

9936(03)01105-1;

Kruopienè J., Dvarionienè J. (2007), Farmaciniy medžiagu patekimo ị Lietuvos gamtinę aplinką keliai, Environmental Research, Engineering \& Management, No. 3(41), p. 33-39;

Kruopienè J., Dvarioniené J. (2010), Management of Environmental Risks in the Life Cycle of Human Pharmaceuticals in Lithuania, Environmental Research, Engineering \& Management, No. 2(52), p. 41-47;

Längin A., Alexy R. König A., Kümmerer K. (2009). Deactivation and transformation products in biodegradability testing of $\beta$-lactams amoxicillin and piperacillin, Chemosphere, No. 75, p. 347-354; http://dx.doi.org/10.1016/j.chemosphere.2008.12.032;

Li W.C. (2014), Occurrence, sources, and fate of pharmaceuticals in aquatic environment and soil, Environmental Pollution, Volume 187, April 2014, p. 193 201; http://dx.doi.org/10.1016/j.envpol.2014.01.015;

Lietuvos Respublikos Valstybès Kontrolè (LRVK), Valstybinio Audito Ataskaita, Medicininiu Atlieky Tvarkymas, $2010 \mathrm{~m}$. lapkričio 17 d. Nr. VA-P-30-2-22, Vilnius;

Lietuvos Respublikos Vyriausybès Nutarimas. 2007 m. spalio 31 d. nutarimo Nr. 1224 redakcija. Dèl Lietuvos Respublikos Vyriausybès $2002 \mathrm{~m}$. Balandžio $12 \mathrm{~d}$. Nutarimo nr. 519 „Dèl valstybinio strateginio atlieku tvarkymo plano patvirtinimo" pakeitimo.

Online

Lithuanian Statistics Department (LSD) Database. http://db1.stat.gov.lt/statbank/SelectTable/Omrade0.asp?PL anguage $=0$

Lyssimachou A., Arukwe A. (2007), Alteration of brain and interrenal StAR protein, P450scc, and Cyp11b mRNA levels in Atlantic salmon after nominal waterborne exposure to the synthetic pharmaceutical estrogen ethynylestradiol, Journal of Toxicology and Environmental Health A, No. 70, p. 606-613;

Mompelat S., Le Bot B., Thomas O. (2009), Occurrence And Fate Of Pharmaceutical Products And ByProducts, From Resource To Drinking Water, Environ. Int., No. 35 , p. $803-814$;

Musson S. E., and Townsend T.G. (2009) Pharmaceutical compound content of municipal solid waste, Journal of Hazardous Materials, No. 162, p. 730-735;

National Center for Biotechnology Information PubChem database of chemical substances; CID 3033, CID 5757, CID 5991; Information Source: The Scripps Research Institute;

Oaks J. L., Gilbert M., Virani M. Z., Watson R. T., Meteyer C. U., Rideout B. A., Shivaprasad H. L., Ahmed S., Chaudhry M. J. I., Arshad M., Mahmood S., Ali A. ir Khan A. A. (2004), Diclofenac residues as the cause of vulture population decline in Pakistan, Nature, No. 427, p. 630-633;
Petrovic M., Gonzalez S., Barcelo D. (2003). Analysis and removal of emerging contaminants in wastewater and drinking water. Trac-Trends Anal. Chem., No. 22, p. 685696;

Plant J.A., Voulvoulis N., Ragnarsdottir K.V. (2012), Teršalai, Žmogaus sveikata ir Aplinka (En.: Pollutants, Human Health and the Environment - A Risk Based

Approach), 8 skyrius - Farmacinès medžiagos ir asmeninès higienos produktai, p. 207, ISBN 978-0-47074261-7;

Robert Loos, JRC Scientific and policy report, Analytical methods relevant to the European Commission's 2012 proposal on Priority Substances under the Water Framework Directive, European Comission, 2012, ISBN 978-92-79-26642-3; ISSN 1831-9424;

Santos J. L., Aparicio I., Alonso E., Callejon, M. (2005). Simultaneous determination ofpharmaceutically active compounds in wastewater samples by solid phase extraction and high-performance liquid chromatography with diode array and fluorescence detectors, Analytica Chimica Acta, No. 550, p. 116-122; http://dx.doi.org/10.1016/j.aca.2005.06.064;

Scheytt T. J., Mersmann P., Heberer T. (2006), Mobility of pharmaceuticals carbamazepine, diclofenac, ibuprofen, and propyphenazone in miscible-displacement experiments, J. Contam. Hydrol., No. 83, p. 53-69; http://dx.doi.org/10.1016/j.jconhyd.2005.11.002;

Scientific Committee on Health and Environmental Risks (SCHER), Opinion on "Chemicals and the Water Framework Directive: Draft Environmental Quality Standards" Ethinylestradiol (EE2), ISSN 1831-4775, ISBN 978-92-79-30643-3, European Union, 2011;

Snyder S. A., Villeneuve D. L., Snyder E. M., Giesy J. O. (2001), Identification And Quantification Of Estrogen Receptor Agonists In Wastewater Effluents, Environmental Science \& Technology, No. 35(18), p. 3620-3625;

Snyder S., Lue-Hing C., Cotruvo J., Drewes J.E., Eaton A., Pleus R.C., Schlenk D., Pharmaceuticals in the Water Environment, National Association of Clean Water Agencies (NACWA), 2010;

Speck U., Wendt H., Schulze P.E., Jentsch D. (1976), Bio-availability and pharmacokinetics of cyproterone acetate-14C and ethinyloestradiol-3H after oral administration as a coated tablet ( $\mathrm{SH}$ B $209 \mathrm{AB}$ ), Contraception, No. 14, p. 151-163; http://dx.doi.org/10.1016/0010-7824(76)90083-4;

Vaistu suvartojimo 2013 metu ataskaita. Valstybinè vaistų kontrolès tarnyba (VVKT). Online at: http://www.vvkt.lt/;

Valstybinè maisto ir veterinarijos tarnyba (VMVT). 2013 m. Valstybinė Gyvūninio Maisto Kontrolè. Online at: http://vmvt.lt/uploads/file/Veiklos\%20ataskaitos/Gyvuninio $\% 20$ maisto\%20kontrole_2013m.pdf;

Wennmalm A. (2011), Reference Module in Earth Systems and Environmental Sciences, Encyclopedia of Environmental Health, Pharmaceuticals: Environmental Effects, p. 462-471; 
Zhang Y., Sven-Uwe G., Carmen Gal (2008), Carbamazepine and diclofenac: Removal in wastewater treatment plants and occurrence in water bodies, Chemosphere, No. 73 (8), p. 1151-1161; http://dx.doi.org/10.1016/j.chemosphere.2008.07.086;

Zhou H., Zhang Q., Ma L., Tu B., Li H., Zhou Y. (2013), Removal of Clofibric Acid and Diclofenac During Anaerobic Digestion of Sewage Sludge, Environment Protection Engineering; No. 4 (39), DOI: 10.5277/epe130406.

MSc student Inga Baranauskaitè - master student of Environmental Engineering, Institute of Environmental Engineering, Kaunas University of Technology.

Main research areas: water resources management, environmental impact assessment, sustainable development.

Address:

K. Donelaičio str. 20, Kaunas

Tel.:

LT - 44239 Lithuania

E-mail.:
Doc. Dr. Jolanta Dvarionienè - assoc. professor, researcher of Environmental Engineering, Institute of Environmental Engineering, Kaunas University of Technology.

Main research areas: water resources management, Integrated Pollution Prevention and Control (IPPC), chemicals control and management, waste management, environmental impact assessment, renewable energy sources.

Address: $\quad$ K. Donelaičio str. 20, Kaunas

Tel.: LT - 44239 Lithuania

E-mail.: $\quad$ Jolanta.Dvarioniene@ktu.lt

\section{Farmacinių medžiagụ (diklofenako, 17- $\beta$-estradiolio, 17- $\alpha$ - etilinestradiolio) buvimas ir aptikimas aplinkoje. Ateities iššūkiai Lietuvai}

\section{Inga Baranauskaitė ir Jolanta Dvarionienė}

Aplinkos inžinerijos institutas, Kauno technologijos universitetas, Kaunas, Lietuva

(gauta 2014 m. birželio mèn., priimtas spaudai 2014 m. birželio mèn.)

Farmacinių medžiagų paplitimas ir migracija vandens cikluose šiuo metu yra tarp labiausiai diskutuotinų bei aplinkosauginiu požiūriu aktualių problemų visame pasaulyje. $2013 \mathrm{~m}$. rugpjūčio $12 \mathrm{~d}$. buvo priimta Europos Parlamento ir Tarybos Direktyva 2013/39/ES, kur pirmą kartą i Stebésenos saraša ịtrauktos farmacinès medžiagos (diklofenakas (DCF), 17- $\beta$-estradiolis (E2) ir 17- $\alpha$-etinilestradiolis (EE2)). Remiantis naujausiais tyrimais, manoma, kad medžiagos gali kelti žalingą poveikị biotai ir gamtinei aplinkai.

Norint numatyti ir valdyti farmacinių medžiagų patekimą i aplinką, svarbu išanalizuoti medžiagų susidarymo šaltinius, pagrindinius vartotojus, taip pat pagrindinius patekimo ị aplinką būdus, suvokti jų gebejimą kisti ir kauptis aplinkoje, norint sumažinti medžiagu nuotèkius.

Tuo tikslu straipsnyje analizuojama farmacinėms medžiagoms (DCF, E2 ir EE2) aplinkoje taikoma teisinè bazè, nustatomas Lietuvoje farmacinių medžiagų (DCF, E2 ir EE2) parduodamas kiekis, pardavimo kitimo tendencijos. Apžvelgiami atlikti tyrimai vertinant šių medžiagų toksikologinę reikšmę gamtinei aplinkai, analizuojami patekimo ị gamtinę aplinką keliai ir šaltiniai, medžiagų skilimas vandens aplinkoje, analizuojama pasaulinè patirtis šalinant farmacines medžiagas iš nuotekų, farmacinių atliekų tvarkymo situacija ir nuotekų tvarkymas Lietuvoje. 